Diabetologia 10, 691-695 (1974)

(c) by Springer-Verlag 1974

\title{
Metabolic Abnormalities in BHE Rats
}

\author{
C.D. Berdanier \\ Carbohydrate Nutrition Laboratory, Nutrition. Institute, Agricultural Research Service, United States Department of \\ Agriculture, Beltsville, Md. 20705, USA
}

Summary. At age 50 days the "carbohydrate sensitive" BHE strain of rat showed hyperinsulinemia which gradually subsided toward normalcy at 10 months. Insulin resistance of adipose tissue and depletion of pancreatic insulin content were evident at age 5 months. The BHE rat showed a tendency to hyperlipemia which increased with age. Prior to the appearance of the hyper- lipemia, the fasting sera contained pre- $\beta$-lipoproteins. The conversion of glucose into lipids in vivo was significantly higher in the hyperinsulinemic BHE rat than in the normoinsulinemic Wistar rat.

Key words: BHE rat, Wistar rat, hyperinsulinemia, hyperlipemia, pre- $\beta$-lipoproteins.

\section{Introduetion}

Nutrition research has been concerned largely with the establishment of quantitative nutritional requirements of groups of animals without regard to strain. Relatively few studies have dealt with the relationship of genetics and specific nutrient requirements or utilization. A few investigators have noted strain differences in protein requirement [1], enzyme activities [25] and carbohydrate utilization [6-11]. Within the last ten years several strains of rodents having the tendency to develop diabetes $[12-19]$ and obesity [20-22] have been recognized.

The "carbohydrate sensitive" $\mathrm{BHE}$ " strain of rat has been used extensively by scientists at the Nutrition Institute for the last 25 years. The strain is a result of a cross between the Osborne-Mendel strain (also called the Yale strain) and the Pennsylvania State College strain. After many years it became apparent that the BHE rats gained more body weight and had more carcass and liver lipids than similarly fed Wistar rats [6$9]$. These differences could not be attributed to differences in food intake [6], and were particularly apparent when the diet contained large amounts of purified carbohydrate $[8,9]$. With the growing interest in carbohydrate induced hyperlipemia [23-29] and the possible relationship between diabetes and heart disease, it was reasonable to suspect that this strain of rat might be useful for the study of relationships between carbohydrates and lipid metabolism.

In our investigations, we were interested in: a) characterizing the insulin status of this strain, b) evaluating the responses of these animals to different diets, and finally, c) determining the relationship between insulin and these metabolic responses.

1 The initials BHE refer to "Bureau of Home Economics", an early predecessor of the present Nutrition Institute,

\section{Methods}

Male BHE and Wistar rats were used, some of which were bred at the Beltsville Nutrition Institute and others at Flow Laboratories in Dublin, Virginia, when the colony was moved there four years ago.

The rats were housed individually in wire mesh cages in a temperature-humidity controlled room. Light was regulated so as to provide equal periods of light and dark. Unless otherwise indicated, the animals were fed diets containing $65 \%(\mathrm{w} / \mathrm{w})$ carbohydrate, $5 \%$ fat, $20 \%$ protein and adequate amounts of vitamins and minerals. Food intakes and body weight gains were determined weekly. For all studies other than tissue sensitivity study, the animals were sacrificed after anesthetization with $90 \mathrm{mg}$ sodium amobar$\mathrm{bitol} / \mathrm{kg}$ weight. Blood was drawn by heart puncture and the appropriate tissues were removed, chilled and weighed. Other experimental details have been described elsewhere [11,30-32].

\section{Results}

Fig. 1 shows that intravenous glucose tolerance was similar in Wistar and in BHE rats. This is an unexpected finding, as overnight fasted BHE rats exhibited significantly higher serum insulin levels at age 50 and 100 days when compared to Wistar rats (Fig. 2). Interestingly, ageing decreased insulin concentrations in BHE rats, but in contrast, increased insulin levels in Wistar animals. By age 300 days there was no significant difference found between the two strains.

In order to find an explanation for these decreasing insulin levels with age in the BHE rats, total pancreatic insulin content was studied at different ages. As shown in Fig. 3, the BHE pancreas contained no more than $10 \%$ insulin by age 150 days when compared with 


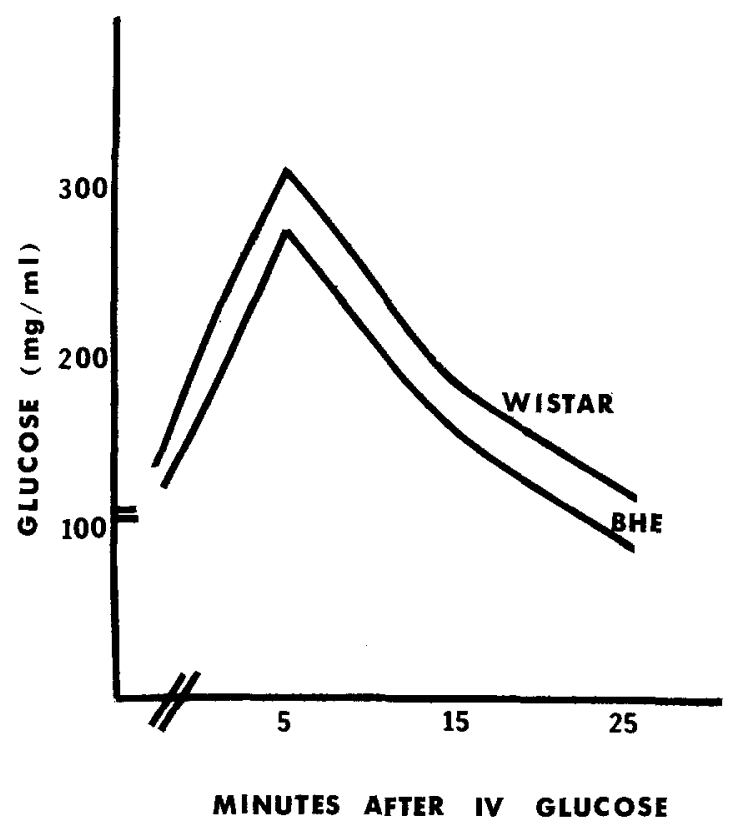

Fig. 1. Blood glucose levels of BHE and Wistar rats 5, 15, and $25 \mathrm{~min}$ after the injection of $1 \mathrm{~g} / \mathrm{kg}$ glucose into the tail vein

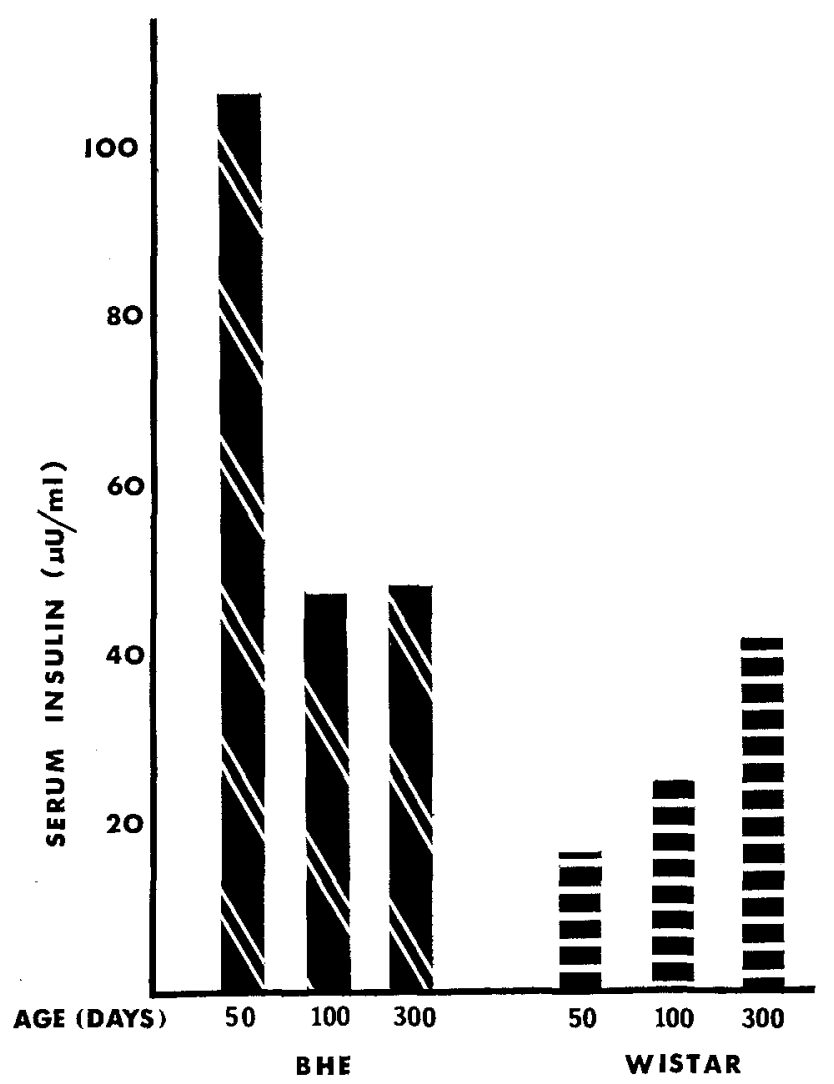

Fig. 2. Fasting serum immunoreactive insulin levels of 50,100 and 300 day old BHE and Wistar rats. (Adapted from ref. 30)

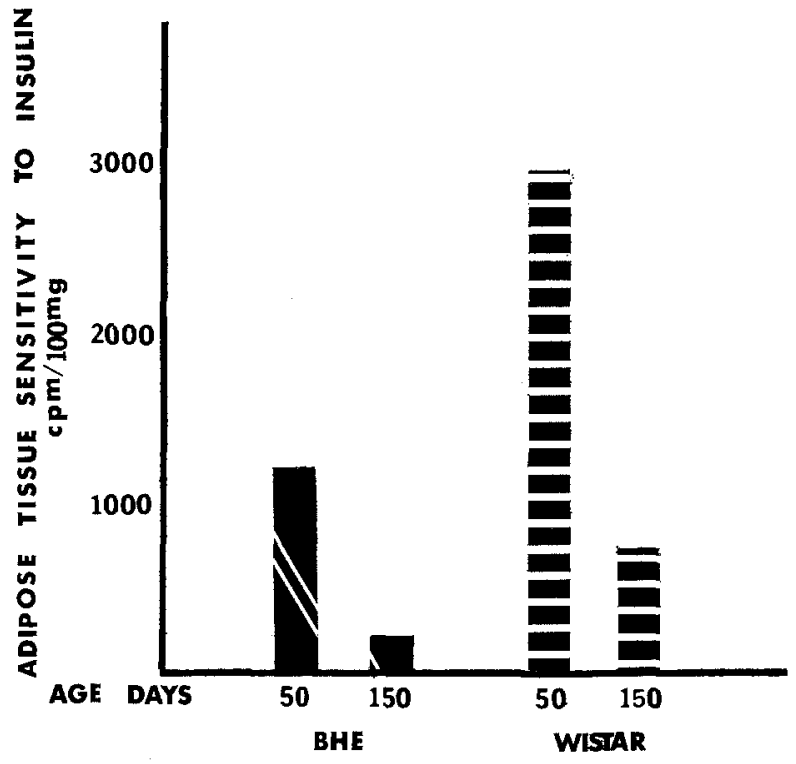

Fig. 3. Adipose tissue sensitivity to insulin of $\mathrm{BHE}$ and Wistar rats at 50 and 150 days of age. Tissue sensitivity is expressed as the difference in counts per minute between basal and insulin stimulated ${ }^{14} \mathrm{CO}_{2}$ release from slices of epididymal fat pads. No age or strain differences in basal ${ }^{14} \mathrm{CO}_{2}$ production were observed. (Adapted from ref. 31)

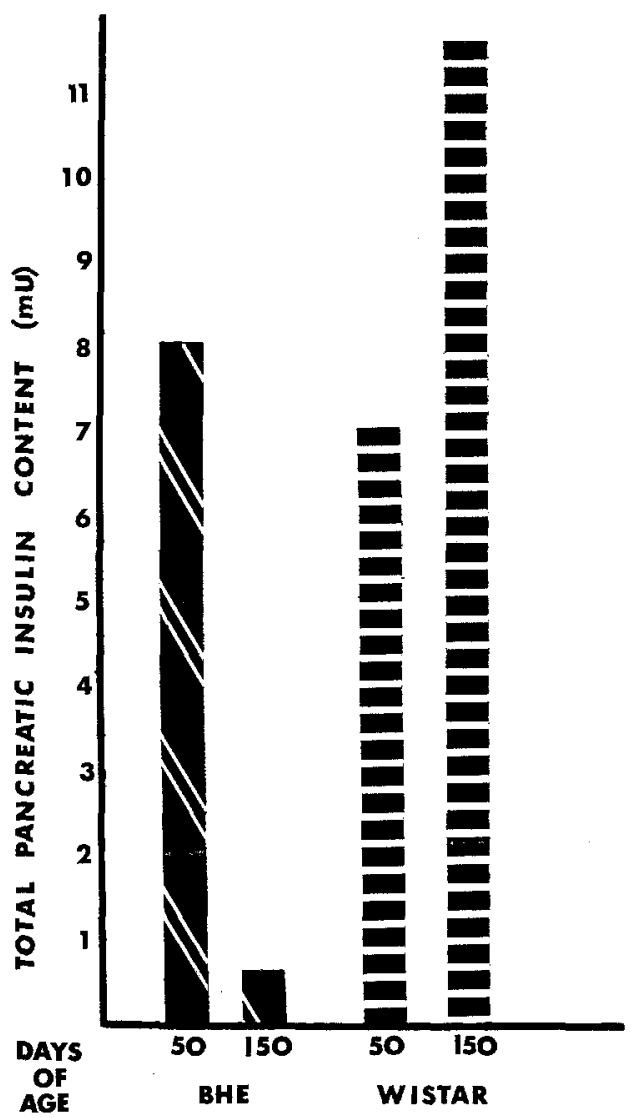

Fig. 4. Total pancreatic insulin content of 50 and 150 day old nonfasted BHE and Wistar male rats. 
age 50 days. Again in contrast, Wistar rats exhibited increasing pancreatic insulin content with age.

These striking differences of serum insulin levels and pancreatic insulin contents in the two strains at different ages would suggest similar differences in tissue

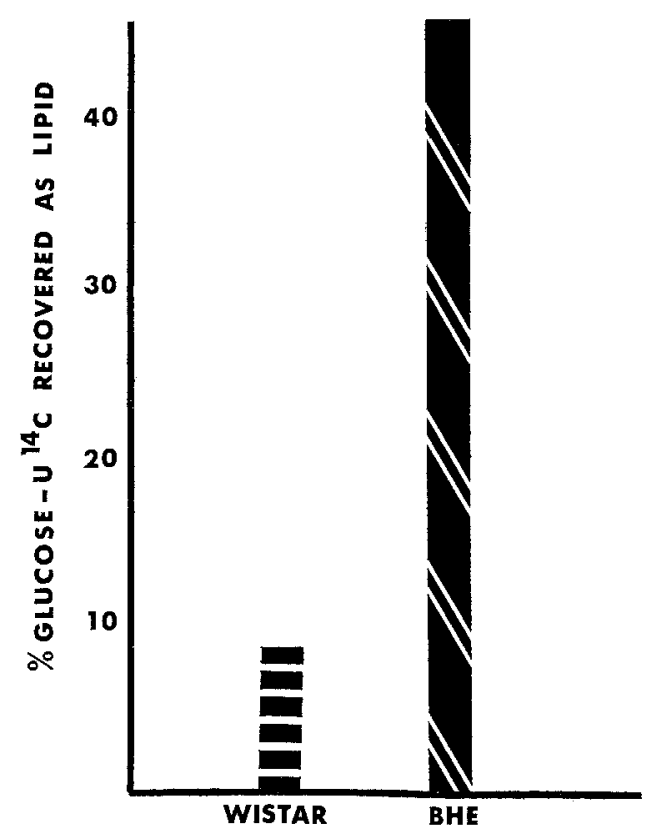

Fig. 5. Percent radioactivity recovered as lipid after the injection of glucose $\mathrm{U}^{\mathrm{I}}{ }^{14} \mathrm{C}, 1 \mathrm{1} \mathrm{Ci} / 100 \mathrm{~g}$ body weight into the portal vein of nonfasted 75 day old BHE and Wistar rats. (Adapted from ref. 32)
Since these in vitro experiments did not correlate with the previously described in vivo results, incorporation of labelled glucose into total body fat was measured in both strains at the age of 75 days when BHE rats exhibited significantly higher serum levels of insulin than Wistar rats. As illustrated in Fig. 5, significantly more glucose was incorporated into total body lipid of BHE rats than was incorporated by Wistar rats.

According to the study of Taylor et al. [8] the effects of various diets were tested in BHE and Wistar rats. Tables 1 and 2 show that the type of diet scarcely influenced serum insulin, triglyceride and cholesterol levels. This may be, in part, secondary to the wide variation of individual values in the BHE rats. It appears clear, however, that Wistar rats fed the same diet showed lower serum levels of insulin as well as triglyceride and cholesterol. It is of particular interest that in no instance did fasting Wistar serum contain pre- $\beta$-lipoproteins. Age increased the levels of cholesterol and triglycerides as shown in Table 3 . This effect was much more marked in BHE rats.

\section{Discussion}

The present study showed that the BHE strain of rats exhibits a marked hyperinsulinemia at a young age. While serum insulin levels increase moderately from $15 \pm 1$ to $39 \pm 2$ at 300 days of age in the Wistar rats, serum insulin dramatically decrease from $99 \pm 7$ to $45 \pm 3$ over this same period in BHE rats. In part,

Table 1. Effect of diet on various components of the sera from overnight fasted $B H E$ and Wistar rats

\begin{tabular}{|c|c|c|c|c|c|c|c|}
\hline & & \multirow{2}{*}{ Diet } & \multirow{2}{*}{$\begin{array}{l}\text { IRIa } \\
50 \text { day }\end{array}$} & \multirow{2}{*}{$\begin{array}{l}\text { Serum } \\
\text { TG } \\
100 \text { day }\end{array}$} & \multirow{2}{*}{$\begin{array}{l}\text { Serum } \\
\text { Chol } \\
100 \text { day }\end{array}$} & \multicolumn{2}{|c|}{$\begin{array}{l}\text { Pre } \beta \\
\text { lipoproteins }\end{array}$} \\
\hline & & & & & & 50 day & 100 day \\
\hline \multirow[t]{8}{*}{ Group } & 1 & $65 \%$ Crude $\mathrm{CHO}$ & $36 \pm 10^{\mathrm{b}}$ & $64 \pm 18$ & $73 \pm 3$ & $3 / 6$ & $3 / 6$ \\
\hline & 2 & $65 \%$ Protein & $36 \pm 11$ & $78 \pm 14$ & $77 \pm 10$ & $0 / 6$ & $2 / 6$ \\
\hline & 3 & $65 \%$ Fat & $41 \pm 10$ & $83 \pm 24$ & $60 \pm 6$ & $0 / 6$ & $0 / 6$ \\
\hline & 4 & $65 \%$ Starch & $37 \pm 13$ & $83 \pm 18$ & $67 \pm 4$ & $2 / 6$ & $5 / 6$ \\
\hline & 5 & $65 \%$ Glucose & $30 \pm 10$ & $79 \doteqdot 14$ & $76 \pm 6$ & $5 / 6$ & $5 / 6$ \\
\hline & 6 & $65 \%$ Sucrose & $33 \pm 10$ & $72 \pm 18$ & $87 \pm 6$ & $5 / 6$ & $5 / 6$ \\
\hline & 7 & $65 \%$ CHO mixture & $31 \pm 9$ & $50 \pm 11$ & $83 \pm 8$ & $2 / 6$ & $4 / 6$ \\
\hline & 8 & $65 \%$ СНО mixture & $37 \pm 8$ & $81 \pm 20$ & $80 \pm 6$ & $4 / 6$ & $5 / 6$ \\
\hline \multicolumn{8}{|c|}{ (2) } \\
\hline & 1 & $65 \%$ Crude $\mathrm{CHO}$ & $23 \pm 2$ & $69 \pm 14$ & $63 \pm 5$ & $0 / 6$ & $0 / 6$ \\
\hline & 2 & $65 \%$ Fat & $20 \pm 1$ & $67 \pm 6$ & $46 \pm 7$ & $0 / 6$ & $0 / 6$ \\
\hline & 3 & $65 \%$ Sucrose & $25 \pm 3$ & $67 \pm 5$ & $69 \pm 6$ & $0 / 6$ & $0 / 6$ \\
\hline
\end{tabular}

a Abbreviations used: IRI, serum immunoreactive insulin; TG, triglycerides; chol, cholesterol; CHO, carbohydrate.

b SEM of 6 rats.

sensitivity. Epididymal adipose tissue in vitro was less sensitive in BHE rats at 50 days of age than in Wistar rats and less sensitive at 150 days of age in both strains to $80 \mu \mathrm{U} / \mathrm{ml}$ of insulin (Fig. 4). Indeed, adipose tissue of both $\mathrm{BHE}$ and Wistar rats decreased ${ }^{14} \mathrm{C}$ glucose oxidation to about $10 \%$ by age 150 days. the hyperinsulinism may be due to the relative insensitivity of the peripheral tissues to insulin and probably contributes to subsequent exhaustion of the islet tissue observed in the older rat. As the peripheral resistance increases, the load of glucose which must be metabolized by the liver increases. With time, the liver 
assumes a greater proportion of the glucose metabolizing function, sending the products of this metabolism, fatty acids, glycerol, glycerides, and cholesterol to the periphery for storage. With the increase in hepatic glucose metabolism the ratio of the liver to peripheral tissue glucose metabolism changes yet the overall glucose metabolism by the body remains unchanged, hence, a normal glucose tolerance exists. Support for this hypothesis is seen in previous papers showing that $\mathrm{BHE}$ rats have greater hepatic glycolytic, pentose shunt, and lipogenic enzyme activities than similarly fed Wistar animals $[3,5]$ and that the livers of BHE animals convert more glucose into lipid and the adipose tissues convert less glucose into lipid than similar tissues of Wistar rats $[10,32]$.

Table 2. Effect of diet on liver and carcass lipid levels of overnight fasted 100 day old male BHE and Wistar rats

\begin{tabular}{|c|c|c|}
\hline & $\begin{array}{l}\% \\
\text { Liver fat }\end{array}$ & $\begin{array}{l}\% \\
\text { Carcass fat }\end{array}$ \\
\hline $65 \%$ Crude Carbohydrate & $4.56 \pm 0.13^{\mathrm{a}}$ & $15.30 \pm 1.28$ \\
\hline $65 \%$ Protein & $3.89 \pm 0.17$ & $11.73 \pm 1.01$ \\
\hline $65 \%$ Fat & $10.75 \pm 1.01$ & $21.17 \pm 2.23$ \\
\hline $65 \%$ Starch & $5.41 \pm 0.77$ & $13.40 \pm 1.18$ \\
\hline $65 \%$ Glucose & $3.88 \pm 0.22$ & $15.59 \pm 1.06$ \\
\hline $65 \%$ Sucrose & $3.76 \pm 0.35$ & $15.76 \pm 2.26$ \\
\hline $45 \%$ Carbohydrate mixture & $4.68 \pm 0.23$ & $14.83 \pm 1.25$ \\
\hline $65 \%$ Carbohydrate mixture & $4.36 \pm 0.33$ & $12.99 \pm 1.07$ \\
\hline \multicolumn{3}{|l|}{ Wistar } \\
\hline $65 \%$ Crude Carbohydrate & $3.98 \pm 0.14$ & $14.43 \pm 1.13$ \\
\hline $65 \%$ Fat & $10.20 \div 1.16$ & $19.38 \pm 1.65$ \\
\hline $65 \%$ Sucrose & $3.73 \pm 0.07$ & $13.04 \pm 0.77$ \\
\hline
\end{tabular}

a SEM of 6 rats.

Table 3. Effect of age on the serum lipids of overnight fasted $B H E$ and Wistar rats continuously fed a $65 \%$ sucrose diet

\begin{tabular}{llcl}
\hline Strain & Age & $\begin{array}{l}\text { Serum } \\
\text { cholesterol } \\
\text { mg/100 ml }\end{array}$ & $\begin{array}{l}\text { Serum } \\
\text { triglycerides } \\
\text { mg/ } / 100 \mathrm{ml}\end{array}$ \\
\hline & & Fasting & Fasting \\
BHE & 200 days & $193 \pm 24^{\mathrm{a}}$ & $144 \pm 22$ \\
Wistar & 200 days & $89 \pm 8^{\mathrm{b}}$ & $220 \pm 14^{\mathrm{b}}$ \\
BHE & 300 days & $270 \pm 31^{\mathrm{c}}$ & $596 \pm 67^{\mathrm{c}}$ \\
Wistar & 300 days & $109 \pm 2^{\mathrm{b}}$ & $273 \pm 17$ \\
\hline
\end{tabular}

a SEM of 6 rats.

b Strain differences significant $(P<0.05)$.

c Age differences significant $(P<0.05)$.

Among several hundred male BHE rats examined, $25 \%$ were completely normal with respect to serum insulin levels and the ability to convert carbohydrate to fat; $25 \%$ were hyperinsulinemic at age 50 days and subsequently developed hyperlipemia; $50 \%$ were intermediate with respect to insulin levels and the efficiency of carbohydrate conversion into lipid.

Although the different diets did not show marked alterations in serum lipid levels, two points are of interest. First, there is a rather clear difference between the two animal strains tested, as Wistar rats show a much lesser tendency to hyperlipemia. Second, it is noteworthy that the BHE rats fed the $65 \%$ fat diet did not contain detectable pre- $\beta$-lipoproteins in plasma (Table 1). Similarly, 65\% protein diet was associated with a very small incidence of pre- $\beta$-lipoprotein. Since the insulin levels were not significantly different in these two groups, one would conclude that the presence of carbohydrate is the essential factor leading to the formation of pre- $\beta$-lipoproteins.

Ageing apparently increases triglyceride and cholesterol levels in rats (Table 3) fed a high sucrose diet. By age 300 days the sera of the BHE animals became creamy in appearance. Although sucrose does not affect the life span of Wistar rats (average life: 800-1000 days), it has been reported to shorten the life of the $\mathrm{BHE}$ rats (average life less than 650 days). The cause of death is, however, open to question, as many BHE rats examined post mortem showed nephrosis.

\section{References}

1. Morris, H.P., Palmer, L.S., Kennedy, C.: Fundamental food requirements for the growth of the rat. Technical Bulletin \# 92 University of Minnesota Agricultural Experiment Station, pp. 3-54, (1933)

2. Bartley, W., Dean, B., Taylor, C.B., Bailey, E.: The effect on some enzymes of rat tissues of diets low in fat content. Biochem. J. 103, 550-555 (1967)

3. Chang', M.L. W., Schuster, E.M., Lee, J.A., Snodgrass, C., Benton, D. A. : Effect of diet, dietary regimens and strain differences on some enzyme activities in rat tissues. J. Nutr. 96, 368-374 (1968)

4. Eggleston, L.V., Krebs, H.A.: Strain differences in the activities of rat liver enzymes. Biochem. J. 114, $877-879(1969)$

5. Berdanier, C.D., Szepesi, B., Moser, P., Diachenko, P.: Insulin and enzyme responses in three strains of rats. Proc. Soe. exp. Biol. (N.Y.) 137, 668-673 (1971)

6. Marshall, M. W., Hildebrand, H.E. : Differences in rat strain response to three diets of different composition. J. Nutr. 79, 227-238 (1963)

7. Adams, M.: Diet as a factor in length of life and in the structure and composition of tissues of the rat with aging. Home Econ. Res. Rept. No. 24, USDA (1964)

8. Taylor, D.D., Conway, E.S., Schuster, E.M., Adams, M.: Influence of dietary carbohydrate on liver content and on serum lipids in relation to age and strain of rat. J. Nutr. 91, 275-282 (1967)

9. Marshall, M. M., Durand, A.M.A., Adams, M. : Different characteristics of rat strains: Lipid metabolism and response to diet. In: Defining The Laboratory Animal, pp. 383-412, Fourth International Symposium of ICLA., Washington, D.C.: Nat. Acad. Sci. 1971

10. Chang, M.L.W., Lee, J.A., Simmons, N.: Rat strain differences in the utilization of glucose $\mathrm{U}^{14} \mathrm{C}$ and acetate ${ }^{14} \mathrm{C}$ for fat synthesis. Proc. Soc. exp. Biol. (N.Y.) 138, 742-747 (1971)

11. Berdanier, C.D.: Metabolic characteristics of the carbohydrate sensitive BHE strain of rat. J. Nutr. (In press) (1974)

12. Dickie, M.M.: Genetics of animals with spontaneous diabetes. In: Early Diabetes, R. Camerini-Davalos, H.S. Cole (eds.) pp 23-27. New York: Academic Press 1970 
13. Renold, A.E.: Spontaneous diabetes and/or obesity in laboratory rodents In: Advances in Metabolic Disorders, Levine, R., Luft, R. (eds.) pp. 49-84. New York: Academic Press 1968

14. Dulin, W.E., Wyse, B.M.: Diabetes in the KK mouse. Diabetologia 6, 317-323 (1970)

15. Iwatsuka, H., Shino, A., Suzuoki, Z.: General survey of diabetic features of yellow KK mice. Endocr. jap. 17, $23-35(1970)$

16. Chick, W.L., Like, A.A.: Studies in the diabetic mutant mouse: IV DBM, a modified diabetic mutant produced by outcrossing of the original strain. Diabetologia 6, 252-256 (1970)

17. Chang, A.Y., Schneider, D.I.: Abnormalities in hepatic enzyme activities during development of diabetes in DG mice. Diabetologia 6, 274-278 (1970)

18. Chang, A. Y., Schneider, D. I. : Metabolic abnormalities in the pancreatic islets and livers of the diabetic chinese hamster. Diabetologia 6, 180-185 (1970)

19. Hummel, K.P., Coleman, D.L.: Diabetes, a new mutation in the mouse. Science 153, 1127-1128 (1968)

20. Mayer, J.: The obese-hyperglycemia syndrome of mice as an example of "metabolic" obesity. Amer. J. clin. Nutr. 8, 712-718 (1960)

21. Bray, G.A., York, D.A.: Genetically transmitted. obesity in rodents. Physiol. Rev. 51, 598-630 (1971)

22. Zucker, T.F., Zucker, L. M. : Fat accretion and growth in the rat. J. Nutr. 80, $6-11$ (1963)

23. Ahrens, E.H., Jr., Hirsch, J., Oette, K.: Carbohydrate-induced and fat induced lipemia. Trans. Ass. Amer. Phycns. 74, 134-146 (1961)

24. Cohen, A.M.: Fats and carbohydrates as factors in atherosclerosis and diabetes in Yemenite Jews. Amer. Heart J. 65, 291--293 (1963)

25. Kaufman, N.A., Gutman, A., Barzilai, D., Eschar, J., Blondheim, S.H., Stein, Y.: Hypertriglyceridemia induced by dietary fat or carbohydrate and by un- controlled diabetes. Israel J. med. Sci. 1, $389-399$ (1965)

26. Kuo, P.T., Basset, D.R. : Dietary sugar in the production of hyperglyceridemia. Ann. intern. Med. 62, $1199-1212(1965)$

27. Cohen, A. M., Kaufmann, N. A., Poznanski, R., Blondheim, S.H., Stein, Y.: Effect of starch and sucrose on carbohydrate induced hyperlipemia. Brit. med. J. 1960 I, $339-340$

28. Fredrickson, D.S., Levy, R. I., Lees, R.S. : Fat transport in lipoproteins: An integrated approach to mechanism and disorders. New Engl. J. Med. 276, $34-44, \quad 94-103, \quad 148-156, \quad 215-225, \quad 273-281$ (1967)

29. Cohen, A.M., Teitelbaum, A., Saliternik, R.: Genetics and diet as factors in the development of diabetes mellitus. Metabolism 21, 235-240 (1972)

30. Berdanier, C.D., Marshall, M.W., Moser, P.B.: Age changes in the level of serum immunoreactive insulin in three strains of rats. Life Sci. 10, 105-109 (1971)

31. Berdanier, C.D., Moser, P.B.: Insulin status of the carbohydrate sensitive BHE rat. Fed. Proc. 30, 579 (1971)

32. Gardner, L.B.: Studies on the conversion of glucose $\mathrm{U}^{14} \mathrm{C}$ to lipid by adipose and hepatic tissues in two strains of rats. M. S. thesis, University of Maryland (1974)

33. Hales, C.N., Randle, P.J.: Immunoassay of insulin with insulin antibody precipitate. Biochem. J. 88, $137-146(1963)$

Carolyn D. Berdanier Carbohydrate Nutrition. Laboratory Nutrition Institute Agricultural Research Service

U.S. Dept. of Agriculture Beltsville, Md. 20705

USA 